\title{
New Approach to Bankruptcy Prediction using Genetic Algorithm
}

\author{
Fariborz ahmadi \\ Department of computer science \\ Ghorveh branch, \\ Islamic azad university, \\ Ghorveh, Iran
}

\author{
saber amjadian \\ Department of accounting science, \\ Ghorveh branch, \\ Islamic Azad University, \\ Ghorveh, Iran
}

\author{
keyhan pardegi \\ Department of accounting science, \\ Ghorveh branch, \\ Islamic Azad University, \\ Ghorveh, Iran
}

\begin{abstract}
In this research the bankruptcy of companies has been surveyed through the genetic algorithm. To do this and in order to design its related genetic model, the financial ratios have been used and a genetic model has been presented in order to predict bankruptcy of the accepted companies in Tehran Stock Exchange Market. Formulating the related model has been done through the relevant data of two groups of the companies accepted as those in Tehran Stock Exchange Market. The first group consists of 40 non-bankrupt companies, and the second one like the first group includes 40 companies but they were bankrupt ones. The model is represented by using 24 financial ratios consisting of 4 groups of liquidation, profitability, activity, and leverage ratios (Capital Structure). The main point of this essay is that unlike the other previous methods which just present the genetic algorithms to solve the problem of predicting bankruptcy, here in this article in addition to focusing on the solution for the problem, the presented model has used the related algorithm in order to learn and converge on the appropriate answer. The test results of the prediction capability of the model indicates the fact that the presented model can predict the companies' bankruptcy and non-bankruptcy accurately and with the least error some years before they really occurs, and by passing the time of bankruptcy, its prediction ability decreases since its prediction indexes become weak gradually. The results of this study present the efficient functions of this method used by different researches.
\end{abstract}

\section{Key Words}

Genetic Algorithm (GA), Prediction, Bankruptcy, Financial Ratios, Tehran Stock Exchange (TSE)

\section{INTRODUCTION}

Financial crisis and the bankruptcy which follows it may have some damaging outcomes for the beneficiaries of the stakeholders of the related companies including stockholders, creditors, and raw materials providers. Meanwhile the role of the accounting information can be determinative to make a distinction between the bankrupt and non-bankrupt companies.

If we can predict financial crisis and the following bankruptcy, we can exploit the investment opportunities properly and also prevent wasting the available sources .It can be done through this procedure ;At first the companies should be on the alert for financial crisis to take the proper preventive actions based on the received warnings, and secondly the investors should determine the favorable investment opportunities from the unfavorable ones and invest their available resources in the proper occasions and opportunities $[8,9]$.

In this research we want to design a model so that predicting companies' bankruptcy can be done by using the accounting information. Since the analysis of financial factors through exploiting the financial ratios is one of the frequent models of analyzing companies, we try to design a model which can predict the bankruptcy of the companies accepted as those in Tehran Stock Exchange Market, through the genetic algorithm and financial ratios. The ratios used in this survey include 24 financial ratios which have been divided into 4 groups of liquidation, leverage (capital structure), activity and profitability ratios.

\section{REVIEW OF RELATED \\ LITERATURE}

Predicting bankruptcy through exploiting the accounting information was formed for the first time by author of [3], he used a one-variable model and tested the accounting ratios. At last he reached this conclusion that at first the ratio of cash flows to the total liabilities can predict bankruptcy with a great potential strength. And after that the ratio of net profit to total assets has this feature, too.

Author of [1] was the first person to present the predictive models to predict bankruptcy based on multi-variable ones. He presented his well-known model called Z-score model by using some multi-variables models and financial ratios. He chose 5 financial ratios which in his opinion were the best ones chosen among 22 ratios and used them to predict bankruptcy. He represented his model by integrating 5 ratios. In the following years some criticisms were made toward his model which made him revise them and improve on the weaknesses of his model himself. Finally he presented the new Z-score model [1] in which

$\mathrm{X} 1=$ Working Capital/ total assets

X2 = Accumulated Profit $/$ Total Assets

X3 = Net Profit before Interests \& Taxes / Total Assets

X4=Book Value of Equity/Book Value of Total Liabilities

$\mathrm{X} 5=$ Sales/Total Assets

$\mathrm{Z}$ : Amount of Dependent Variable Gained from the Model (General Index)

$\mathrm{Z}<1.21=$ Bankrupt Companies

\section{$\mathrm{Z}>$ 2.90: Non-bankrupt Companies}

Authors of [7] used the model of incremental analysis in order to predict bankruptcy. The ratios which he used are cash flows to sales, the cash flows to the total assets, the cash flows to the specific value, and the cash flows to the total debts. Their two sample groups were based on the size and the kind of the designed industry. The results of their investigations indicated that working cash flows to total assets and cash flows to total liabilities are the best positive indexes to predict bankruptcy three years before the real bankruptcy occurs [7]. 
Authors of [11] used the financial ratios of liquidity, operating, and leverage to represent his model. These ratios were not selected theoretically or based on a particular theory; rather he chose them based on his experiences from his previous studies. The model of $\mathrm{He}$ was based on a sample, involving 40 bankrupt companies and 80 non-bankrupt ones. In this model he used the ratios of net profit to total assets, total liabilities to total assets, and current asset to current liabilities. This is one of the simplest models to predict bankruptcy in which the principle of few numbers of independent variables has been considered accurately [11].

Author of [7] used the discriminate analysis in order to consider and analyze his model. He found out that this model can predict the health of companies in terms of bankruptcy and non-bankruptcy nearly $94 \%$ in the first year before occurring the real bankruptcy, $80 \%$ in the second year, and $70 \%$ in the third, the forth and the fifth year. It was proven that the best index of predicting bankruptcy in the model was the ratio of total liabilities to cash flows among the other variable although the general relative importance of the ratios could not be determined obviously [7].

During the recent years, many studies have been done through using the ways of soft computing to predict bankruptcy including the methods of fuzzy logic genetic algorithm, birds' migration algorithm, and ants' algorithm and the artificial neural networks which the previous researches in this field and explaining all of them is not possible now.

The present study uses the genetic algorithm to solve the problem. The only difference is that in spite of the previous genetic algorithm that were used before to solve the problem of predicting bankruptcy, here in this article in addition to focusing on the solution for the problem, the presented model has used the related algorithm in order to learn and converge on the appropriate answer.

\section{THE NOVEL APPROACHES IN PREDICTING BANKRUPTCY}

Soft computing methods such as genetics, neural networks, ant colony, etc are used to solve the NP-hard problems (nondeterministic polynomial -time problems) $[13,14]$. In this essay the researchers have used the genetic algorithm in order to present a model for predicting bankruptcy. In order to solve the problem, 24 parameters which have the potential power to show a company's bankruptcy or non-bankruptcy have been used to compose the chromosomes of the present study based on genetic algorithms. The parameters are as follows:

\section{Current Ratio}

2. Current Assets Ratio

3. Quick Ratios

4. Cash Flows / Total Assets

5. Cash Flows / Total Liabilities

6. Cash Flows / Total Current Liabilities

7. Cash Flows / Sales

8. Debt Ratios

9. Owner's Equity /Total liabilities

10. Current debts to Net Worth Ratio3

11. Long-term debts to Net Worth Ratio
12. Possessory Ratio

13. Frequency of Inventory Turnover Utilization

14. Inventory Turnover Period

15. Assets Turnover

16. Inventory to Working Capital

17. Working Capital turnover

18. Return on Sales Ratio

19. Gross Profit Ratio

20. Operating Profit Ratio

21. Return on Net worth Ratio

22. Return on Common Equity Ratio

23. Return on Assets Ratio

24. EPS

\section{3-1: Chromosomes Structure}

The structure of chromosomes has a large amount of influence on the findings of the solution. The researchers have used chromosomes with 24 fields to store and show the candidate solutions, and each field indicates one of the above parameters. Each field has a decimal number showing the effect of the related parameter on the company's bankruptcy or non-bankruptcy.

The following figure indicates the structure of one chromosome:

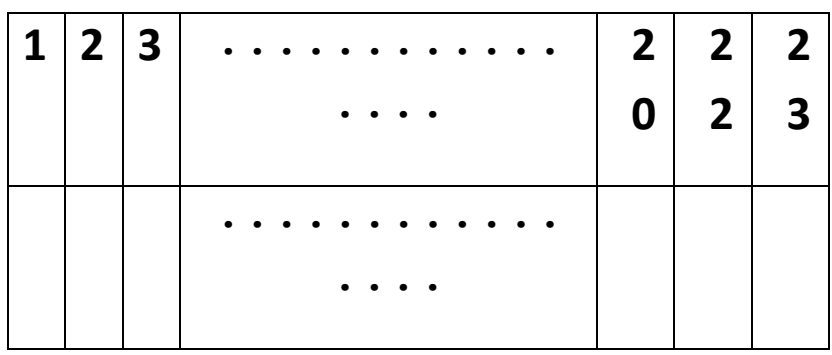

\section{3-2: Genetic Population}

The genetic population of this solution includes 1000 chromosomes illustrated above .The first population is produced randomly-directed. For instance, the ratio of operational current flows to total current liabilities should normally be a positive measure, but in some cases this measure is negative and the company is non-bankrupt regarding the other five companies; Therefore, in producing the first population of chromosomes, a positive measure is assigned to the related field so that the results be closer to the exact result, but there is a possibility of the related field to become negative in crossover and mutation operations. The measures of each field in the first population are based on the following parameters:

$\mathrm{B}=0.4 \quad$ “ $1<$ Current Ratio $<2 ”$
$\mathrm{~B}=0.4 \quad$ " $0.1<$ Current Assets Ratio $<0.8 ”$
$\mathrm{~B}=0.4 \quad$ " Quick Ratios $=1 "$
$\mathrm{~B}=0.6 \quad$ "Cash Flows / Total Assets $>0 "$
$\mathrm{~B}=0.6 \quad$ "Cash Flows / Total Liabilities $>0 "$
$\mathrm{~B}=0.6 \quad$ "Cash Flows / Total Current Liabilities $>0 "$
$\mathrm{~B}=0.6 \quad$ "Cash Flows / Sales $>0 "$




\begin{tabular}{|c|c|}
\hline $\mathrm{B}=0.3$ & " $0<$ Liability Ratios <0.5" \\
\hline $\mathrm{B}=0.3$ & " Debt to Equity Ratio $\geq 1 "$ \\
\hline $\mathrm{B}=0.3$ & “ $-1<$ Current debts Net Worth Ratio" $<1$ \\
\hline $\mathrm{B}=0.3$ & “ $-1<$ Long-term debts to Net Worth Ratio $<1$ " \\
\hline $\mathrm{B}=0.2$ & “ $-0.5<$ Possessory Ratio <0.5" \\
\hline $\mathrm{B}=0.3$ & "Frequency of Inventory Turnover Utilization >1" \\
\hline $\mathrm{B}=0.3$ & “ Inventory Turnover Period <90" \\
\hline $\mathrm{B}=0.2$ & "Assets Turnover $\mathrm{x}>0 "$ \\
\hline $\mathrm{B}=0.3$ & " $0<$ Inventory to Working Capital $<2 "$ \\
\hline $\mathrm{B}=0.4$ & "Working Capital turnover $>1 "$ \\
\hline $\mathrm{B}=0.7$ & "Return on Sales Ratio >0" \\
\hline $\mathrm{B}=0.3$ & "Gross Profit Ratio >0" \\
\hline $\mathrm{B}=0.5$ & "Operating Profit Ratio $>0 "$ \\
\hline $\mathrm{B}=0.4$ & "Return on Net Worth Ratio>0" \\
\hline $\mathrm{B}=0.4$ & "Return on Common Equity Ratio $>0 "$ \\
\hline $\mathrm{B}=0.7$ & " Return on Assets Ratio >0" \\
\hline $\mathrm{B}=0.5$ & "EPS $>0 "$ \\
\hline
\end{tabular}

By forming the first population the related crossover and mutation operations are done on the chromosomes. The main difference of this method with the previous ones is the reality that the problem is solved by using genetic algorithm. The results of this study showed a kind of superiority of this method to other ones $[1,3,7,11]$.

In this study the researchers have used a predetermined number called $R$. If the total amount of multiplying the product of the chromosomes ' field by the company's related parameter is more than $\mathrm{R}$, the company is non-bankrupt and if this number is less than $R$, the company is regarded as bankrupt. In order to find the problem's solution, information of 100 companies has been used. Among them fifty companies are bankrupt and the others are non-bankrupt. Now, the solution to the problem is a chromosome that its fitness function is more than $\mathrm{R}$ for all of the non-bankrupt companies, and it is less than $\mathrm{R}$ for all companies which are bankrupt. Suppose C is the number of the companies, I the number of chromosomes, $\mathrm{J}$ the number of chromosomes' field and the company's parameters, $\mathrm{H}$ the number of healthy (nonbankrupt) companies, and B the number of bankrupt ones; so the solution to the problem will be:

$$
\begin{aligned}
& \forall_{c H} \quad \sum_{J=1}^{24} \quad i_{j} \cdot c_{j} \geq R \\
& i_{j} . c_{j} \prec R \quad \sum_{J=1}^{24} \quad \forall_{c B}
\end{aligned}
$$

The genetic algorithm will be stopped when such a chromosome is achieved.

\section{3-3: Fitness Function}

The way of calculating the fitness function is based on the above formula. At first this function is zero for all of the chromosomes. If the amount is more than $\mathrm{R}$ for a healthy (non-bankrupt) company, the number"1" will be added to its amount, and also if is less than $\mathrm{R}$ in a bankrupt company, the number "1" will be added too; otherwise, if its amount for healthy company be less than $\mathrm{R}$ and for bankruptcy company be more than $\mathrm{R}$, the number 1 is decreased from its fitness.

It is obvious that if the fitness function of one chromosome is equal to 100 , that chromosome will be the solution of the problem. The pseudo-code of the fitness function operation is as follows:

For every companies

If company is health and

$$
\sum_{J=1}^{24} i_{j} \cdot c_{j} \succ 1
$$

then FITNESS

Else nothing endif

If company is backruptcy and

$$
\sum_{J=1}^{24} i_{j} \cdot c_{j} \prec 1
$$

then FITNESS

Else nothing endif

End for

It should be noticed that if the fitness function is equal to the number of the companies which are the subjects of this research, it will be the solution of the problem, and if the fitness function of a chromosome is equals to negative of the number of companies, that chromosome considers all of the bankrupt companies as healthy (non-bankrupt), and all of the healthy (non-bankrupt) companies as bankrupt.

\section{3-4: Genetic Selection}

Tournament and Roulette methods can be used in the genetic selection $[12,16,17]$. The results of evaluation indicate that selection of any of these methods have the same effect on the convergence of the genetic algorithm towards the solution.

\section{3-5: Crossover Operations}

Since one decimal number is assigned for each field in this method, single-point and two-point crossovers can be used. When chromosomes $\mathrm{P}$ and $\mathrm{S}$ are chosen for the crossover operation, they will be integrated according to their relative fitness function. It means that if the fitness function of the chromosome $\mathrm{P}$ is two times more than the fitness function of the chromosome $\mathrm{S}$, the effect of the chromosome $\mathrm{P}$ will be two times more than the chromosome $S$ in creating the offspring Q. Suppose the field of any chromosome is shown by $\mathrm{J}$, then creating the offspring $\mathrm{Q}$ to predict the next generation will be as follows:

$$
\forall{ }_{J} Q_{J}=\frac{\text { fitness }_{P} . P_{J}+\text { fitnes }_{s} . S_{J}}{\text { fitness }_{P}+\text { fitness }_{S}}
$$

Here one important fact is that in this method just one chromosome is produced when the two selected chromosome recombined with each other. In order to solve this problem, the selection of the operator must be done $\mathrm{n}$ times in each operator generation, and in each operation two chromosomes must be chosen. So the number of the selections of the operators will be $2 \mathrm{n}$ chromosome which results in producing $n$ chromosomes, it should be noted that $\mathrm{n}$ indicates the number of one generation or population which in this research equals 1000 . 


\section{3-6 Mutation Operators}

The mutation operation will be done after the crossover operation [12]. The possibility of mutation is 0.001 in this research. On the other hand, in some cases, the reduction of the chromosome's fields, and in some other cases, the increase of the fields has been used to satisfy mutation operator. The pseudo-code of the mutation is as follow:

- $\quad$ Generating a random number between 0 and 1; say (p): for mutation operations

- Generating a random number between 0 and 1; say (d): to determine the operations of multiplying and dividing

- Generating a random number between 0 and 1; say (d): to determine the field of the mutation operations - If $P \leq 0 / 001$ then

\begin{tabular}{|c|c|}
\hline $\begin{array}{l}\text { - } \text { If } \quad \text { round } \\
i_{J}=i_{J} \cdot(1+P) \\
\text { End if } \\
\text { - } \quad \text { If round (d)=1 then } \\
\text { - } \quad \text { End if } \\
\text { - } \quad \text { End if }\end{array}$ & $\begin{array}{c}\text { (d) }=0 \\
i_{J}=i_{J} /(1+P)\end{array}$ \\
\hline
\end{tabular}

\section{MODEL ASSESSMENT}

In order to assess the model's ability, the information of the financial statements of the sample companies has been used to the year of bankruptcy and the related ratios of 80 companies presented in the model have been operated several times. The followings are the results of these operations:

\begin{tabular}{|c|c|c|c|c|c|}
\hline \multirow{2}{*}{$\begin{array}{l}\text { The } \\
\text { Sample } \\
\text { Groups }\end{array}$} & \multirow[t]{2}{*}{$\begin{array}{c}\text { All the } \\
\text { Companies }\end{array}$} & \multicolumn{2}{|c|}{$\begin{array}{l}\text { The Predicted Percentage by } \\
\text { the Model }\end{array}$} & \multirow{2}{*}{$\begin{array}{c}\text { The Percentage } \\
\text { of All the } \\
\text { Companies }\end{array}$} & \multirow{2}{*}{$\begin{array}{c}\text { The Total Exactness in } \\
\text { the Original Sample of } \\
\text { the Model }\end{array}$} \\
\hline & & $\begin{array}{c}\text { Percentage of } \\
\text { Bankrupt }\end{array}$ & $\begin{array}{l}\text { Percentage of } \\
\text { Non- } \\
\text { Bankrupt }\end{array}$ & & \\
\hline Bankrupt & 40 & $91 \%$ & $0.09 \%$ & 100 & $89 \%$ \\
\hline $\begin{array}{c}\text { Non- } \\
\text { Bankrupt }\end{array}$ & 40 & $87 \%$ & $0.13 \%$ & 100 & \\
\hline
\end{tabular}

The results indicate that the model has classified $89 \%$ of the total sample correctly. The first type of errors is just $9 \%$, and the second type is $13 \%$, and it indicates the model's high capability to determine the bankrupt and health (nonbankrupt) companies.

\section{CONCLUSION}

The summary of the research's results are as follows:The information of the financial factors has information values to predict bankruptcy. The financial ratios have the ability to predict companies' bankruptcy.

The results of this research are in line with the findings of [1, $2,3]$. Hopefully through exploiting this model, we can prevent incurring losses to the beneficiaries of stakeholders of companies and the economics of different countries, and also help them to be able to predict bankruptcy and prevent its destructive consequences before occurring.

\section{REFERENCES}

[1] Altman.E. I.(1968, September). Financial ratios, discriminant analysis and the Prediction of corporate bankruptcy. The Journal of Finance,23(4).589-609.

[2] Altman.E. I.(2000) Prediction Financial Distress of Companies: Revisiting the Z-Score and Zeta Models. New Tork University.
[3] Beaver,W.H. Financial ratios as predictors of failure Journal of Accounting Research,4, Empirical Research in Accounting: Selected Studies, (Supplement), (1966), pp.71-111.

[4] Casey,C. and N. Bartczk. (1985). Ushng Operating Cash Flow data To predict Financial Distress: Some Exention. Journal of Accounting Research. Pp.384-401.

[5] I.M.Premachandra(2008,November) DEA as a tool for bankruptcy assessment. European journal of Operational Research.Pp.179-195.

[6]Joseph(2002,September).AdvancedCorporateFinance,Pere ntice HahhL; first edition.

[7] Jodi Bellovary (2007,Jan). Journal of Financial Education, Volum 33, A Reviev of Bankruptcy Prediction Studies: 1930 to Present.

[8] Veston \& brigham, management finance, 4 th ed,1943.

[9] Van Horne, J . Financial Management and Policy. 7th ed. Englewood Cliff N.J, Prentice-Hall Inc.1986

[10] William H. Beaver. 'Financial Rations as Predictiors Of Failure " In Empirical Research in Accounting, May 1966, p.121.

[11] Zmijewski marke (1984), Method Logical Issues Relate to the Estimate of Financial Distress Prediction Model, Journal of accounting Reasearch Vol 22 supplemen. 
[12] Goldberg D., and R. lingle, traveling salesman problem , proc of an international conference on genetic algorithm and their applications, 1985.

[13]Srinivas, M., Patnaik, L. M. (1994), "Genetic Algorithms: A Survey",IEEE Trans. Computer,June 1994.

[14] Srinivas, M., Patnaik, L. M. (1994), "Adaptive Probabilities of Crossover and Mutation in Genetic Algorithms", IEEE Trans. Systems, Man and Cybernetics, Apr.1994.
[15] Goldberg d., Genetic algorithm in search optimization and machine learning, Addison-welsey publishing, 1989.

[16] Haritigan, J.A., clustering algorithms, jhon wiley \& sons, 1975.

[17] Jakobovic, D. (1997) "Adaptive Genetic Operators in limination Genetic Algorithm", Proc. 19th International Conference ITI'97, Pula, 17-20 June 1997, pp.351-356 